Available online at https://jurnal.stmikroyal.ac.id/index.php/jurdimas

\title{
PEMANFAATAN MEDIA SOSIAL SEBAGAI MEDIA INFORMASI UPT. PUSKESMAS PORSEA
}

\author{
Abdul Karim Syahputra ${ }^{1}$, Edi Kurniawan ${ }^{1}$, Nofriadi $^{1}$ \\ ${ }^{1}$ Sistem Komputer, STMIK Royal Kisaran \\ email :"abdulkarim.syahputra@gmail.com
}

\begin{abstract}
Community service activities which are given the title "Use of Social Media As Information Media UPT. Porsea Health Center" aims to provide information to all Porsea people about health openly. The method used in this activity is direct observation to the healt center by retrieving data along with documentation from Porsea health center all of which will later be poured out on social media. other than that, data and information collection also carried out by the lecturer team as the perpetrator of this service activity by direct interview to staff and employees which is in the Porsea health center. The final result of this service utilize social media as information giver to porsea society equipped with supporting pictures.
\end{abstract}

Keywords: Social Media, Information, Helath Center, Whatsapp

\begin{abstract}
Abstrak: Kegiatan pengabdian kepada masyarakat yang diberi judul "Pemanfaatan Media Sosial Sebagai Media Informasi UPT. Puskesmas Porsea" bertujuan untuk memberikan informasi kepada seluruh masyarakat porsea tentang kesehatan secara terbuka. Metode yang digunakan dalam kegiatan ini adalah observasi langsung ke puskesmas dengan mengambil datadata beserta dokumentasi dari puskesmas Porsea yang nantinya akan dituangkan semuanya media sosial. Selain itu, pengumpulan data dan informasi juga dilakukan tim dosen selaku pelaku kegiatan pengabdian ini dengan cara wawancara langsung kepada staf dan pegawai yang ada di lingkungan puskesmas Porsea. Hasil akhir dari pengabdian ini adalah memanfaatkan media sosial sebagai pemberi informasi kepada masyarakat Porsea dilengkapi dengan gambargambar pendukung
\end{abstract}

Kata kunci: Sosial Media, Informasi, Pusat Kesehatan, Whatsapp

\section{PENDAHULUAN}

Perkembangan puskesmas di Indonesia kini semakin pesat. Masingmasing puskesmas berlomba lomba menyediakan pelayanan terbaik bagi pasiennya, termasuk dengan memberikan fasilitas-fasilitas yang memudahkan pasien untuk berobat.
Salah satu fasilitas pendukung puskesmas yang ada di Indonesia adalah dengan pemberian akses informasi yang mudah bagi masyarakat melalui media sosial. Puskesmas Porsea sendiri memiliki website pribadi yang dapat memberikan informasi kepada masyarakat mengenai keadaan puskesmas itu sendiri, namun 
Available online at https://jurnal.stmikroyal.ac.id/index.php/jurdimas

penyampaian informasi melalui website ini masih dianggap kurang maksimal, berdasarkan hasil wawancara yang dilakukan pada warga sekitar puskesmas porsea, bahwasannya website yang ada saat ini sangat sulit digunakan karena perlunya web browser khusus untuk mengaksesnya ditambah lagi informasi yang disediakan diwebsite juga belum cukup lengkap . Hal ini menjadi masalah tersendiri bagi masyarakat yang ingin memperoleh informasi mengenai puskesmas Porsea.

Seiring dengan banyaknya masyarakat yang tinggal di daerah Porsea dan sekitarnya, menyebabkan keberadaan UPT Puskesmas Porsea ini menjadi hal yang pokok yang harus diketahui oleh masyarakat setempat. Masyarakat yang akan mengakses layanan kesehatan ke puskesmas Porsea wajib mengetahui kondisi dan kesiapan puskesmas agar mendapatkan pelayanan terbaik. Sering mereka harus bertanyatanya dan bahkan tersesat informasi, padahal di zaman era informatika seperti ini harusnya informasi seperti itu bukanlah hal yang sulit didapat, apalagi dengan banyaknya pengguna ponsel pintar di Indonesia dan khususnya di porsea, dimana perangkat ponsel pintar ini menawarkan berbagai kemudahan di dalamnya sehingga diperlukanlah sebuah media informasi tambahan selain website yang mudah dan praktis yang dapat diakses setiap saat. Yaitu melalui dengan memanfaatkan aplikasi sosial media.

Perkembangan media sosial yang semakin pesat tidak hanya terjadi pada negara-negara maju saja, di negara berkembang seperti tanah air kita ini, Indonesia saja banyak sekali user atau pengguna sosial media dan perkembangan yang pesat ini bisa menjadi pengganti peran media massa atau konvensional dalam menyebarkan berita atau informasi.

\section{Pengertian Media Sosial}

Menurut Putra (2012) yang dikutip oleh (Budiyono, 2016) Media sosial adalah sebuah media online, dimana para penggunanya bisa dengan mudah memanfaatkannya untuk memenuhi kebutuhan komunikasinya. Konsep lain mengatakan bahwa media sosial merupakan media online yang mendukung interaksi sosial. Implementasinya, media sosial menggunakan teknologi berbasis web yang mengubah komunikasi menjadi dialog interaktif.

Perkembangan media sosial yang semakin pesat tidak hanya terjadi pada negara-negara maju saja, di negara berkembang seperti tanah air kita ini, Indonesia saja banyak sekali user atau pengguna sosial media dan perkembangan yang pesat ini bisa menjadi pengganti peran media massa atau konvensional dalam menyebarkan berita atau informasi. Selain itu, Indonesia menempati peringkat ke $5 \mathrm{di}$ dunia dalam pengguna akun twitter. selain untuk membagi informasi, media sosial maupun internet juga dapat dijadikan sebagai suatu kegiatan bisnis, seperti membuka toko online dan sebagainya.

\section{Manfaat Media Sosial}

Berikut ini beberapa manfaat yang dirasakan dengan menggunakan media sosial dikutip dari laman trivia.id.

1. Mudah terinspirasi dan menjadi lebih kreatif

2. Kamu dapat berteman dan terhubung dengan siapa pun 
Available online at https://jurnal.stmikroyal.ac.id/index.php/jurdimas

3. Jika beruntung, kamu juga bisa bertemu dengan jodohmu!

4. Tak ada lagi sekat dalam berkomunikasi

5. Beragam peluang bisnis bisa kamu temukan

6. Kamu semakin mudah mengetahui apa yang sedang terjadi di dunia

7. Menemukan orang-orang yang satu frekuensi denganmu.

\section{Media Sosial Populer}

1. Facebook

Facebook adalah salah satu media sosial berbasis web yang memiliki banyak fitur atau fasilitas mulai dari Cerita (Story) yang lebih dikenal orang sebagai Postingan atau "status", Teman, Album Foto dan Video, Grup, Halaman Penggemar, Iklan, Game, Acara, Chat, Video Call hingga fasilitas untuk menyelenggarakan Siaran Langsung (Live Streaming)

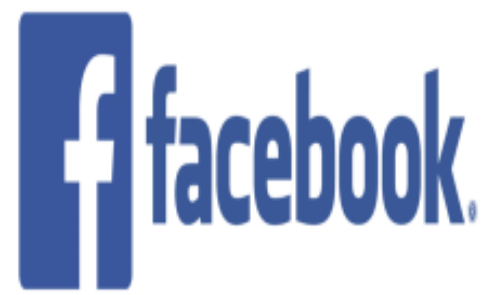

\section{Gambar 1. Simbol Facebook}

2. Instagram

Instagram adalah sebuah aplikasi berbagi foto dan video yang memungkinkan pengguna mengambil foto, mengambil video, menerapkan filter digital, dan membagikannya ke berbagai layanan jejaring sosial, termasuk milik Instagram sendiri. Satu fitur yang unik di Instagram adalah memotong foto menjadi bentuk persegi, sehingga terlihat seperti hasil kamera Kodak Instamatic dan polaroid.

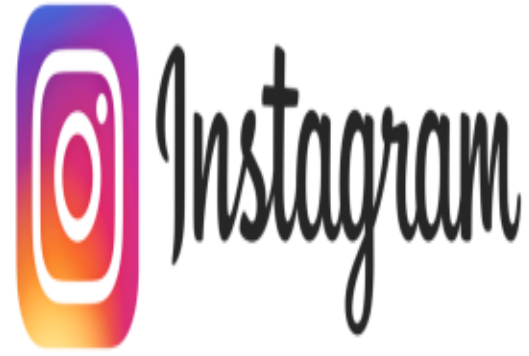

Gambar 2. Simbol Instagram

3. WhatsApp

Whatshap Messenger atau WhatsApp saja adalah aplikasi pesan untuk smartphone dengan basic mirip BlackBerry Messenger. WhatsApp Messenger merupakan aplikasi pesan lintas platform yang memungkinkan kita bertukar pesan tanpa biaya SMS, karena WhatsApp Messenger menggunakan paket data internet yang sama untuk email, browsing web, dan lainlain. Aplikasi WhatsApp Messenger menggunakan koneksi $\underline{3 \mathrm{G}, 4 \mathrm{G}}$ atau WiFi_untuk komunikasi data.

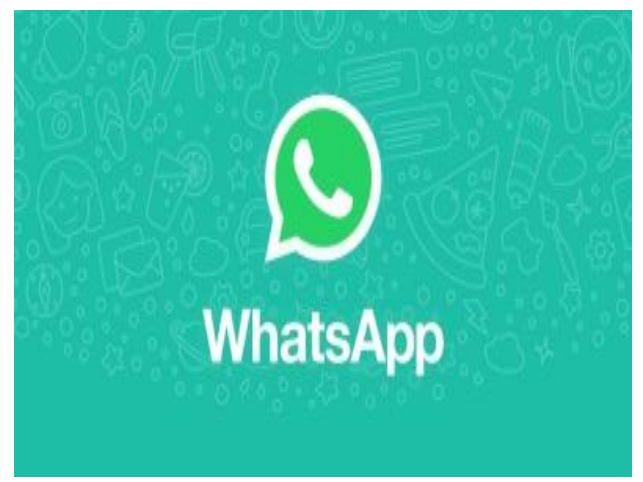

Gambar 3. Simbol Whatshap

\section{METODE}

Metode pelaksanaan dalam pengabdian masyarakat ini meliputi 
penyampaian materi, pengumpulan data dengan wawancara Penguraian materi dimulai dari motivasi tentang teknologi hingga pengoperasian dan optimalisasi aplikasi nantinya. Pengumpulan data dilakukan dengan wawancara dan mengambilan dokumentasi melalui gambar-gambar puskesmas Porsea. Sedangkan pemanfaatan sosial media sebagai media informasi dilakukan melaui apliaksi sosial media yang banyak digunakan dilinkup porsea yaitu Facebook, instagram dan Whatsapp. kemudian di pasang di smartphone android masing-masing pihak puskesmas Porsea.

Berikut beberapa dokumentasi kegiatan pengabdian kepada masyarakt di puskesmas Porsea :

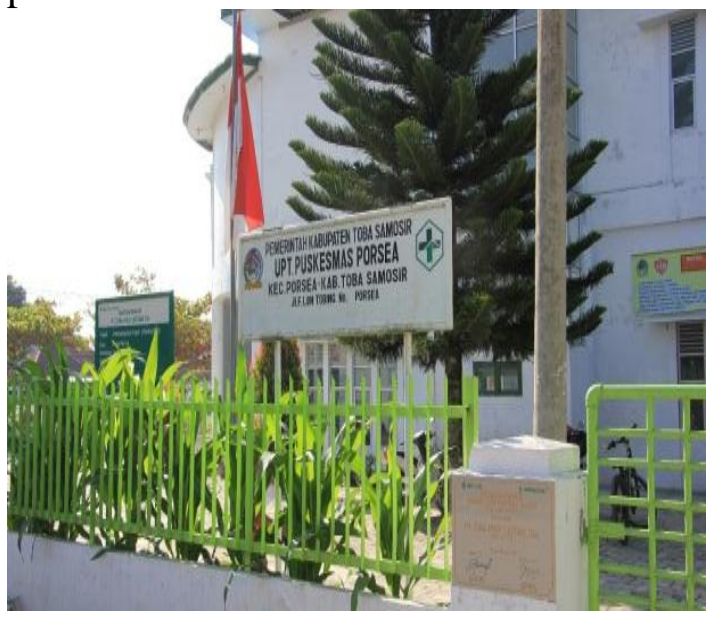

Gambar 4. Gerbang Puskesmas

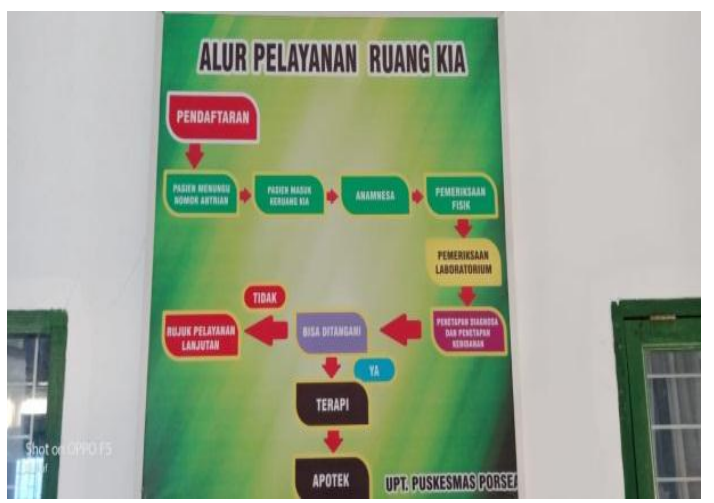

Gambar 5. Alur Pelayanan

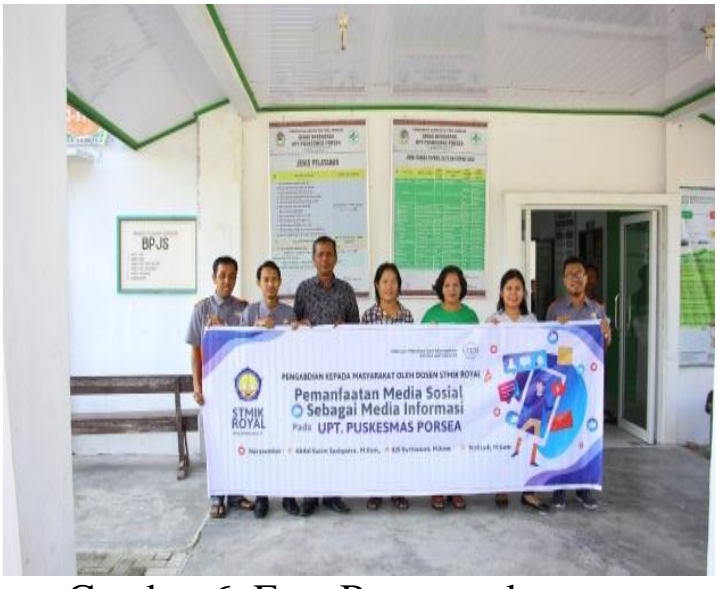

Gambar 6. Foto Bersama dengan

Kepala Puskesmas

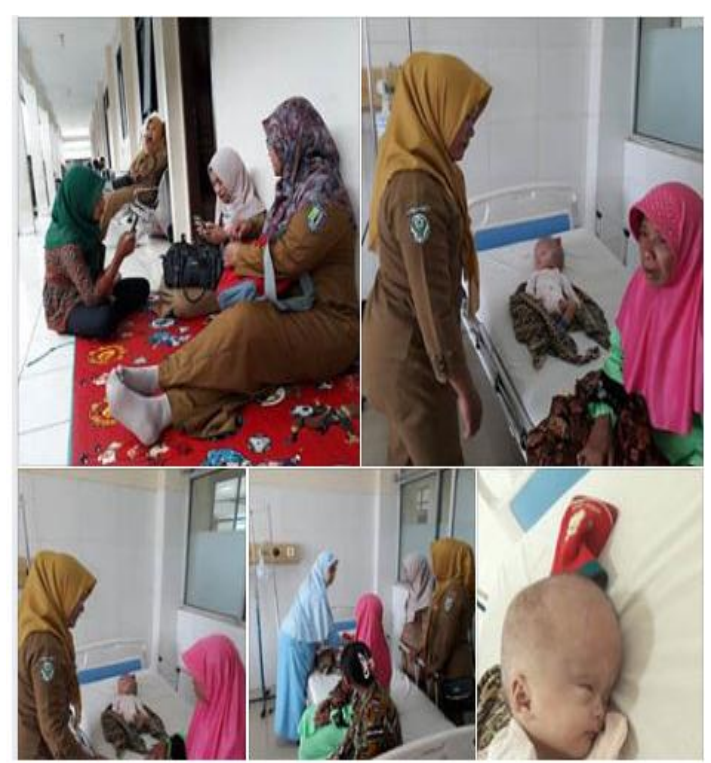

Gambar 7. Pelayanan di Puskesmas

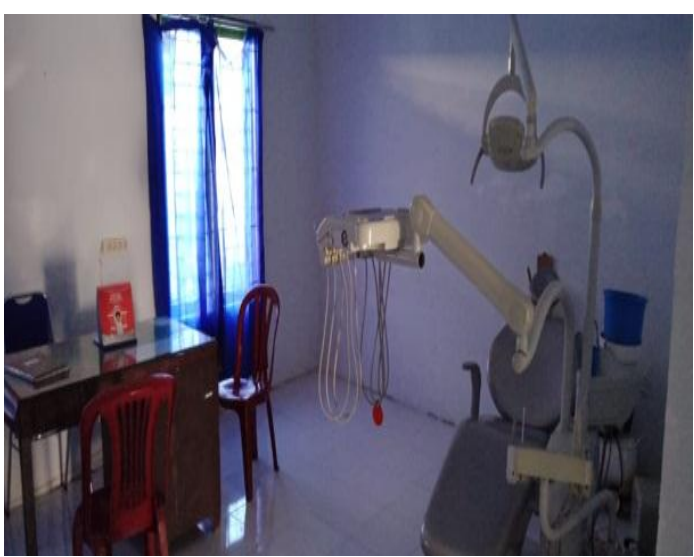

Gambar 8. Ruangan IGD Puskesmas 


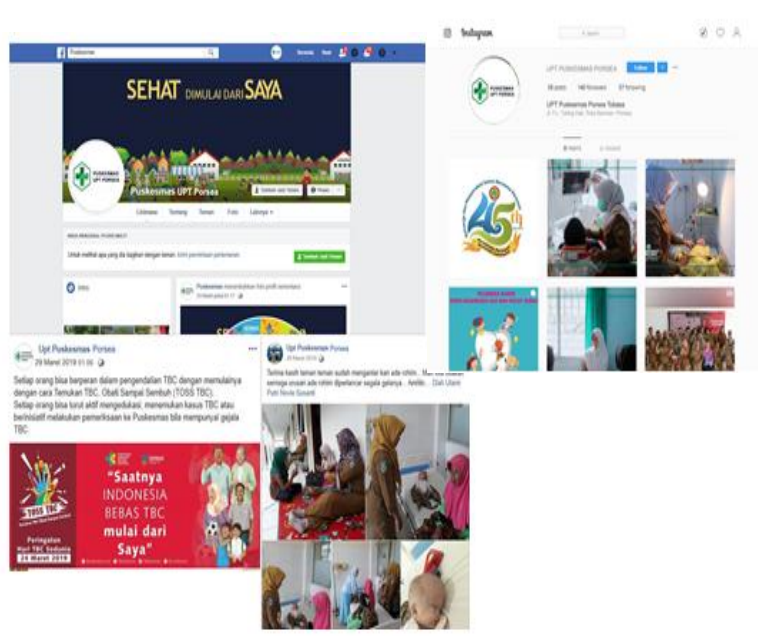

Gambar 9. Implementasi Manajemen Informasi Sosial Media Pada Puskesmas

\section{PEMBAHASAN}

Sesuai dengan rencana pelaksanaan pengabdian masyarakat mengenai tema "Pemanfaatan Media Sosial sebagai Media Informasi UPT. Puskesmas Porsea" ,maka kegiatan tersebut telah direalisasikan sesuai dengan rencana dan berjalan dengan lancar dan efektif. Hal ini dikarenakan banyaknya dukungan dari berbagai pihak baik STMIK Royal Kisaran melalui LPPM, pihak UPT Puskesmas Kecamatan porsea, serta Kepala dan pegawai UPT Puskesmas Kecamatan porsea. Adapun kegiatan ini dilaksanakan pada tanggal 23 Maret 2019 antara pukul $08.00 \mathrm{~s} / \mathrm{d} 17$.

Dari hasil pelatihan yang telah dilakukan kepada para pegawai UPT Puskesmas Kecamatan porsea tersebut di atas dapat telah dirasakan sangat bermanfaat. Hal ini berdasarkan hasil pemanfaatan media social sebagai media informasi yang telah selesai berdasarkan arahan Kepala dan pegawai UPT Puskesmas Kecamatan porsea. Keberhasilan ini juga didasari dari testimoni para Kepala dan pegawai UPT Puskesmas Kecamatan porsea yang menyampaikan bahwa selama ini belum pernah ada, sehingga melalui kegiatan ini dapat memberikan informasiinformasi tentang prosedur layanan yang ada pada UPT Puskesmas Kecamatan porsea. Adapun hasil yang didapat adalah sebagai berikut:

1. Memanfaatakan media sosial sebagai media informasi untuk Puskesmas Kecamatan porsea telah berhasil dirancang dan dapat bermanfaat bagi Kepala dan pegawai UPT Puskesmas dan masyarakat pada umumnya.

2. Pemanfaatan media sosial pada UPT Puskesmas Kecamatan porsea sudah berhasil dan dapat memberikan kemudahan dalam penyampaian informasi kepada masyarakat porsea.

\section{SIMPULAN}

Kesimpulan dari Kegiatan Pengabdian Masyarakat ini adalah:

1. Dapat memberikan manfaat untuk Kepada dan pegawai di UPT Puskesmas Kecamatan Porsea dalam hal pelayanan informasi pada UPT Puskesmas Kecamatan Porsea.

2. Para Pegawai UPT Puskesmas Kecamatan Porsea dapat memahai cara pemanfaatan media sosial sebagai media informaisi. 
Jurdimas (Jurnal Pengabdian Kepada Masyarakat) Royal

Vol. 2 No. 2, Juli 2019, hlm. 115 - 120

DOI: https://doi.org/10.33330/jurdimas.v2i2.370

ISSN 2622-3813 (Online)

Available online at https://jurnal.stmikroyal.ac.id/index.php/jurdimas

\section{DAFTAR PUSTAKA}

Budiyono., 2016. "Media Sosial dan Komunikasi Politik: Media Sosial sebagai Komunikasi Politik Menjelang PILKADA DKI JAKARTA 2017." Jurnal Komunikasi. E-ISSN: 2548-7647
Yuliana, I., Santosa, P. I. dan Setiawan, N. A., 2015. "Analisis Jejaring Media Sosial untuk Pemetaan pada Komunitas Online." Seminar Nasional Aplikasi Teknologi Informasi (SNATi). ISSN: 19075022 